\title{
Mechanical Ventilation Practices of Turkish Emergency Physicians: A National Survey
}

\author{
Türk Acil Tıp Hekimlerinin Mekanik Ventilasyon Uygulamaları: \\ Bir Ulusal Anket Çalışması
}

\author{
Erhan DÜZENLi, Mustafa SEVER, Ersin AKSAY \\ Department of Emergency Medicine, Tepecik Training and Research Hospital, Izmir
}

\begin{abstract}
SUMMARY
Objectives

The objective of this study is to ascertain the mechanical ventilation management skill perception levels of emergency physicians in Turkey as well as to determine the infrastructural condition of ED in Turkey with respect to mechanical ventilation.
\end{abstract}

\section{Methods}

We distributed a survey to all emergency physicians in Turkey. The contents of the survey consisted of 4 main areas that paralleled the objectives of the study. (1) Socio-demographic characteristics, (2) the situation of the personnel and the technical infra-structure in the ED (3) the Emergency Medicine Training Program (EMTP) and post graduate training, and (4) suggested solutions. Each physician's perception level was evaluated with a $10 \mathrm{~cm}$ Visual Analogue Scale.

\section{Results}

Four-hundred emergency physicians participated in the study (response rate $=70.5 \%$ ). The means of the emergency physicians' perceptions as to whether or not the personnel and technical infrastructure for mechanical ventilation management are adequate in the institutions in which they work were $3.2 \pm 2.4 \mathrm{~cm}$ and $3.4 \pm 2.4 \mathrm{~cm}$, respectively. It was determined that $75.5 \%$ of the participants did not receive any education regarding mechanical ventilation management during their emergency medicine education program. The means of the physicians' perception levels regarding the number of times they practiced mechanical ventilation during their emergency medicine education program was $4.6 \pm 2.2 \mathrm{~cm}$, and the means of their perception levels regarding their own knowledge and skills on mechanical ventilation management was $5.4 \pm 2 \mathrm{~cm}$. It was determined that during mechanical ventilation, $29.5 \%$ of emergency physicians had not used any sedative agents, and $30.2 \%$ of them had not used any paralyzing agents. It was also determined that midazolam (30.7\%) was used most frequently for sedation, fentanyl $(50.7 \%)$ was used most often for analgesia, and vecuronium (27\%) was used most frequently as a neuromuscular blocker. The most frequently reported problem regarding formal mechanical ventilation management set forth by the participants was that theoretical and practical education was not standard.

\section{Conclusions}

The skill perception level of emergency physicians regarding mechanical ventilation management is low. Having an intensive care unit in the emergency department or having a clinic chief who is an emergency physician as director increased the perception level of physicians who participated in an emergency medicine education program about mechanical ventilation management. Both the mechanical ventilation management education in emergency medicine education programs and the infrastructural conditions of emergency departments with respect to mechanical ventilation were considered to be inadequate by emergency physicians.

Key words: Emergency department; emergency physician; mechanical ventilation; resident training; simulation laboratory.

\section{ÖZET}

Amaç

Amacımız, Türkiye'deki acil tıp uzmanlarının mekanik ventilasyon yönetimi beceri algı düzeylerini ve acil servislerin mekanik ventilasyon konusunda altyapı durumunu tespit etmektir.

\section{Gereç ve Yöntem}

Türkiye'deki tüm acil tıp uzmanlarına yönelik bir anket uygulandı. Çalışma amacına yönelik anket formu içeriği, dört ana başlıktan oluşturuldu. (1) Sosyo-demografik özellikler, (2) Acil servisteki personel ve teknik alt yapı durumu (3) Acil Tıp Eğitim Programı (ATEP) ve mezuniyet sonrası eğitimler, (4) Çözüm önerileri. Algı düzeyleri $10 \mathrm{~cm}$ 'lik Görsel Analog Skala ile değerlendirildi.

\section{Bulgular}

Bu çalışmaya 400 acil tıp uzmanı katıldı (geri dönüş oranı = \%70.5). Acil tıp uzmanlarının bulundukları kurumların, personel ve teknik altyapılarının mekanik ventilasyon yönetimi için yeterli olup olmadığına dair algı düzeylerinin ortalamaları, sırasıyla $3.2 \pm 2.4 \mathrm{~cm}$ ve $3.4 \pm 2.4 \mathrm{~cm}$ tespit edildi. Katılımcıların \%75.5'inin acil tıp eğitim programı süresince mekanik ventilasyon yönetimi konusunda hiç eğitim almadıkları saptandı. Acil tıp eğitim programı süresince mekanik ventilasyon uygulama sayısı yeterliliği algı düzeyleri ortalama değeri $4.6 \pm 2.2 \mathrm{~cm}$, mekanik ventilasyon yönetimi konusunda bilgi ve beceri algı düzeyleri ortalama değeri $5.4 \pm 2 \mathrm{~cm}$ olarak saptandı. Acil tıp uzmanlarının mekanik ventilasyon süresince, \%29.5'inin sedatif, \%30.2'sinin paralizan ajanlardan herhangi birini kullanmadığı saptandı. Sıklıkla sedasyon için midazolam (\%30.7), analjezi için fentanil (\%50.7) ve nöromusküler bloker olarak ise vekuronyum (\%27) kullandıkları saptandı. Katılımcıların formal mekanik ventilasyon yönetimi eğitimiyle ilgili en sık öngördüğü sorun teorik ve girişimsel beceriler eğitiminin standart olmamasıdı.

\begin{abstract}
Sonuç
Acil tıp uzmanlarının mekanik ventilasyon yönetimi konusunda beceri algı düzeyleri düşüktür. Acil serviste yoğun bakım ünitesi bulunması veya klinik şefinin acil tıp kökenli bir yönetici olması, acil tıp eğitim programı alan hekimlerin mekanik ventilasyon yönetimi konusunda başarı algılarını artırmaktadır. Mekanik ventilasyon konusunda acil servislerin altyapıları ve acil tıp eğitim programlarındaki mekanik ventilasyon yönetimi eğitimlerinin her ikisinin de acil tıp uzmanlarınca yetersiz bulunduğu tespit edildi.
\end{abstract}

Anahtar sözcükler: Acil servis; acil tıp uzmanı; mekanik ventilasyon; asistan eğitimi; benzetim laboratuvarı.

Submitted (Geliş tarihi): 05.04.2013 Accepted (Kabul tarihi): 25.06.2013 Published online (Online baskı): 18.07.2013

Correspondence (iletişim): Dr. Mustafa Sever. Manavkuyu M. 275/10 S. N: 12, Platinium Sitesi,

C Blok, D: 4, 35330 İzmir, Turkey.

e-mail (e-posta): adanasever@yahoo.com

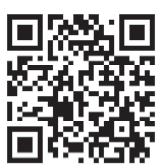

Türkiye Acil Tıp Dergisi - Tr J Emerg Med 2013;13(3):119-126 doi: 10.5505/1304.7361.2013.57689 


\section{Introduction}

The number of patients referring to emergency departments (ED) with complaints of serious respiratory distress has increased in recent years. Fourteen percent of ED referrals include patients with respiratory distress. ${ }^{[1]}$ Mechanical ventilation (MV) is being used in the ED, often for the treatment of critical patients. ${ }^{[2]}$

MV is often utilized by emergency physicians (EP). ${ }^{[3]}$ Even though most patients breathing via a mechanical ventilator in the ED are only there for a short time, this type of ventilation management is among the most appropriate. ${ }^{[4]}$

To our knowledge, there has been no study in Turkey evaluating the personal opinions of emergency physicians regarding mechanical ventilation management (MVM). Our primary objectives are to determine (1) the MVM skill perception levels of EP and (2) the condition of EDs regarding MV.

\section{Materials and Methods}

\section{Location, Duration, and Ethics of the Study}

The study was performed at tertiary emergency medicine clinics that provide specialized education in emergency medicine. The study includes the emergency medicine clinics of 37 state university hospitals, 3 private/charitable foundation university hospitals, 27 state training and research hospitals, 23 private hospitals, and 86 state hospitals. Approval from the Local Ethics Council was obtained prior to the start of the study.

\section{Research Methods and Sampling}

Our study is a survey study that includes all of the EPs ( $n=567$, according to December 2011 data) in Turkey. We aimed to include a minimum of $60 \%$ of all of the EPs in Turkey. Survey forms were sent to EPs by cargo and e-mail. Some of the data were collected via face to face interviews with some of the participants. Survey forms that had missing data regarding the primary objective of the study were excluded.

\section{Materials Used in the Study}

Survey forms prepared by the researchers consisted of 4 main areas that paralleled the objectives of the study (1). These 4 areas included (1) socio-demographic characteristics, (2) the situation of the personnel and the technical infra-structure in the ED (3) the Emergency Medicine Training Program (EMTP) and post graduate training, and (4) suggested solutions.

The Visual Analogue Scale (VAS) was used to determine the adequacy of the personnel and technical equipment used for mechanical ventilation at each clinic and the adequacy of the MVM (invasive and non-invasive) skills of the EPs. ${ }^{[5,6]}$ VAS values were graded as follows: $0 \mathrm{~cm}$ : very inadequate, 1-3 $\mathrm{cm}$ : inadequate, 4-5 cm: neither adequate nor inadequate, 6-8 cm: adequate, $9-10 \mathrm{~cm}$ : more than adequate.

\section{Methods of Analysis}

All data were recorded and all analyses were performed in the Statistical Package for Social Sciences (SPSS) 17.0 program. The relationships between the normally-distributed parameters were analyzed with the Shapiro-Wilk test and non-parametric tests were used for non-normal distributions. Mann-Whitney $U$ tests and chi-square tests were used for non-parametric (qualitative) variables. Parametric (quantitative) data are expressed as number of observations and percentages (\%), and qualitative data are presented as $95 \%$ confidence intervals, means \pm standard deviation, or medians (minimum-maximum). A Pearson analysis was used for correlation analyses between numeric variables, and Spearman Correlation Analysis was used for correlation analyses between ordinal variables. A value of $p<0.05$ was accepted as statistically significant.

\section{Results}

\section{Research population}

$400 \mathrm{EPs}$ participated in the survey (response rate $=70.5 \%$ ). $34.9 \%$ of the participants worked at University Hospitals (UH), 30.7\% worked at Training and Research Hospitals (TRH), $7.2 \%$ were at Private Hospitals (PH), and $26.9 \%$ were at State Hospitals (SH).

\section{Socio-Demographic Properties}

315 of the participants $(78.6 \%)$ were male, and their mean age was $35.4 \pm 3.7$ years (29-49 years). The mean duration of specialization of the participants was $48.5 \pm 44.2$ months (1-192 months) and the mean duration in the profession of medicine was $127 \pm 47.2$ months ( $72-288$ months). Both the mean duration in the profession of medicine and the mean duration of specialization were higher for EPs who worked in UHs and PHs than of those of who worked in other institutions ( $p=0.001$ and $p=0.021$, respectively).

\section{Factors Effecting Skill Perception Level}

\section{Manpower and physical infrastructural qualifications of clinics and hospitals}

$85.5 \%$ of the participants stated that there were no intensive care units (ICU) in their EDs. $23.5 \%$ of the EPs who stated that their EDs had ICUs were working at UHs and $20.3 \%$ of them were working at TRHs. The mean skill level perception of the participants who had ICUs in their EDs with respect to MV 
was higher than that of the others $(7.4 \pm 3 \mathrm{~cm}$ vs. $5.4 \pm 2 \mathrm{~cm}$, $\mathrm{p}=0.001$, respectively).

The total number of beds in the hospitals of the participants was indicated as either $<200$ or $\geq 200$, and their frequency of monitoring intubated patients was categorized as "never, rarely or intermittently" or "frequently or always". It was observed that the greater the total number of beds in the hospitals correlated with a greater frequency of monitoring intubated patients in EDs ( $p=0.013)$.

The participants' mean adequacy perception level of personnel infrastructure for MVM in the EDs in which they are working was $3.2 \pm 2.4 \mathrm{~cm} .12 .2 \%$ of the participants perceived the personnel infrastructure for MVM as "very inadequate". The mean perception level for "adequacy of technical equipment" was $3.4 \pm 2.4 \mathrm{~cm}$. $10.7 \%$ of the participants $(n=43)$ perceived the technical equipment infrastructure in their EDs as "very inadequate." The distribution of the means of "personnel and technical equipment adequacy" perception levels of each type of institution is shown in Table 1.

The mean "effort shown for MVM" perception level of the EPs who perceived the personnel infrastructure condition in their clinics as adequate was $7 \pm 1 \mathrm{~cm}$ and those who perceived it as very adequate was $5.4 \pm 2 \mathrm{~cm}(p=0.016)$. However, no difference was observed between the mean "skill level for MVM" perception level of the participants whose perception of "personnel and technical equipment" infrastructure was adequate and very adequate $(5.4 \pm 1 \mathrm{~cm}$ personnel vs. $5.2 \pm 2$ $\mathrm{cm}$ equipment, $\mathrm{p}=0.0625$ and $4.9 \pm 2 \mathrm{~cm}$ personnel vs. $5 \pm 3$ $\mathrm{cm}$ equipment, $\mathrm{p}=0.058$, respectively).

\section{Personal training and clinical infrastructure qualifications}

75.5\% of EPs ( $n=302)$ never had a hands-on MVM training during their EMTP, while 23\% ( $n=92$ ) had at least one handson training, and $1.5 \%$ received more than one hands-on trainings.
$74.7 \%$ of the participants stated that they did not attend any training program or class on MVM after completion of their EMTP. 20\% of the EPs attended at least one hands-on training program or class on MVM after graduation and $5.2 \%$ of EPs had more than one hands-on training.

Participating physicians whose clinic chiefs were EPs had more training on MVM ( $\geq 2$ times) both during and after EMTP than those whose clinic chiefs were not EPs $(p=0.019$ and $p=0.022$, respectively). The mean skill perception levels of MVM of EPs who received training on MVM during their EMTP was found to be higher than those who did not $(6.7 \pm 1$ $\mathrm{cm}$ vs. $5.2 \pm 3 \mathrm{~cm}, \mathrm{p}=0.002$, respectively).

The mean MVM skill perception level of the participants whose clinic chiefs were EPs was higher than those whose clinic chiefs were not EPs $(7.1 \pm 3 \mathrm{~cm}$ vs. $5.3 \pm 2 \mathrm{~cm}, p=0.004$, respectively).

The mean MVM skill perception level of the participants who received training on MVM after graduation was higher than those who did not receive any training $(7.2 \pm 2 \mathrm{~cm}$ vs. $5.1 \pm 4$ $\mathrm{cm}, \mathrm{p}=0.006$, respectively).

There were no simulation laboratories in the EDs or hospitals of $93 \%$ of the participants. There was no difference between the skill perception level of participants who had simulation laboratories in their clinics and those who did not $(5.7 \pm 3 \mathrm{~cm}$ vs. $5.3 \pm 1 \mathrm{~cm}, \mathrm{p}=0.289$, respectively).

\section{Personal adequacy and skill level}

$16.5 \%$ and $16.7 \%$ of the participants perceived themselves as "very inadequate" in invasive and non-invasive MV (CPAP, BIPAP) applications, respectively. The mean skill perception level of EPs for invasive MV was $5.4 \pm 2 \mathrm{~cm}$ and was $5.6 \pm 2 \mathrm{~cm}$ for non-invasive MV (CPAP, BIPAP). The distribution of the personal opinions of the participants on $\mathrm{MV}$ applications during the emergency medicine training programs at each institution is shown in Table 2.

Table 1. Distribution of means of "personnel and technical equipment adequacy condition" perception levels per institution

\begin{tabular}{lcc}
\hline Institution & $\begin{array}{c}\text { Personnel infrastructure } \\
\text { adequacy mean of VAS values } \mathbf{( c m )}\end{array}$ & $\begin{array}{r}\text { Technical equipment infrastructure } \\
\text { adequacy mean of VAS values } \mathbf{( c m )}\end{array}$ \\
\hline Training and Research Hospitals & $4.35 \pm 2.18$ & $4.51 \pm 2.05$ \\
University Hospitals & $4.08 \pm 2.19$ & $4.39 \pm 2.32$ \\
State Hospitals & $1.35 \pm 1.19$ & $1.46 \pm 1.19$ \\
Private Hospitals & $0.84 \pm 1.67$ & $1.01 \pm 1.73$ \\
All participants & $3.2 \pm 2.4$ & $3.4 \pm 2.4$ \\
\hline
\end{tabular}

VAS: Visual Analogue Scale; cm: Centimeter. 
Table 2. Distribution of personal opinion of participants on mechanical ventilation applications during emergency medicine training program per institution

\begin{tabular}{lcccc}
\hline Institution & $\begin{array}{c}\text { NIMV Application } \\
\text { Skill VAS Values } \\
\text { Mean }(\mathbf{c m})\end{array}$ & $\begin{array}{c}\text { Patient Monitoring } \\
\text { Skill with MV } \\
\text { VAS Values } \\
\text { Mean (cm) }\end{array}$ & $\begin{array}{c}\text { MVA Number } \\
\text { Adequacy } \\
\text { VAS Values } \\
\text { Mean (cm) }\end{array}$ & $\begin{array}{c}\text { MV Use Effort and } \\
\text { Responsibility } \\
\text { Adequacy VAS } \\
\text { Values Mean (cm) }\end{array}$ \\
\hline Training and Research Hospital & $6.4 \pm 2$ & $5.8 \pm 2.2$ & $5.2 \pm 2.5$ & $5 \pm 2.51$ \\
University Hospital & $6.2 \pm 1.8$ & $6.3 \pm 1.7$ & $4.8 \pm 2.5$ & $3.1 \pm 2.6$ \\
State Hospital & $4 \pm 1.4$ & $4.1 \pm 1.5$ & $3.8 \pm 1.4$ & $2.8 \pm 1.6$ \\
Private Hospital & $4.2 \pm 1.2$ & $3.9 \pm 1.3$ & $4.1 \pm 1.5$ & $4.1 \pm 1.6$ \\
All participants & $5.6 \pm 2$ & $5.4 \pm 2$ & $4.6 \pm 2.2$ & $3 \pm 0.9$ \\
\hline
\end{tabular}

NIMV: Non-invasive Mechanical Ventilation; MV: Mechanical Ventilation; MVA: Mechanical Ventilation Application; VAS: Visual Analogue Scale, cm: Centimeter.

The duration of the specialization experience of the participants was categorized as either $<48$ months or $\geq 48$ months, and their MVM skill perception levels were grouped as $<6$ and $\geq 6$. The mean MVM skill perception levels of EPs whose experience durations were $\geq 48$ months was found to be higher than those who had $<48$ months experience $(6.7 \pm 3$ cm vs. $5.6 \pm 4 \mathrm{~cm}, \mathrm{p}=0.003$, respectively).

$34 \%$ of EPs perceived the number of MV applications they performed during EMTP as inadequate (including non-invasive applications like (PAP and BIPAP). The mean adequacy perception level of the participants for numbers of MV applications was $4.6 \pm 2.2 \mathrm{~cm}$. The mean "Effort and responsibility adequacy" perception level of $46.7 \%$ of EPs was $3 \pm 0.9 \mathrm{~cm}$ for MVM (Table 2).

\section{Mechanical Ventilation Management Properties}

\section{Mechanical ventilation indications}

The participants indicated that the most frequent MV indications were acute respiratory distress (91.2\%) and trauma (64.1\%). These were followed by out-of-hospital cardiac arrest (52.5\%), acute loss of consciousness (51.1\%), cardiogenic shock (17\%), and other reasons requiring application.

\section{Mechanical ventilation properties (monitoring frequency, devices, drugs)}

$44.7 \%$ of the participants never monitored intubated patients in their clinics, while $12.2 \%$ of them monitored intubated patients all of the time. $40.2 \%$ of the participants used a single use automatic ventilator (e.g.: Surevent ${ }^{\oplus}$ ) instead of a classical mechanical ventilation device for invasive mechanical ventilation. $30.2 \%$ of EPs did not use any paralyzing agents and $29.5 \%$ of them did not use any sedative agents during intubation or in the monitoring phase (after intubation) (Table 3).
The most frequently preferred sedative agent was midazolam (30.7\%) and the most preferred combination was midazolam + propofol (14.7\%). EPs never used ketamine and etomidate alone for sedation during intubation or in the monitoring phase (after intubation). EPs working in TRHs and UHs frequently preferred vecuronium as neuromuscular blocking agent (33.5\%, 37.3\%, respectively), while those working in SHs preferred vecuronium less frequently (12.9\%) or they used vecuronium + succinylcholine $(12.9 \%)$ during intubation or in the monitoring phase.

Fentanyl was the most frequently preferred analgesic agent by EPs during and after intubation $(50.7 \% ; n=203)$. Participants working in TRHs, UHs and PHs frequently preferred fentanyl $(78 \%, 62.8 \%, 20.6 \%$ respectively), while those working in SHs frequently preferred morphine sulfate (44.4\%). $16 \%$ of the participants did not use any analgesic agents during or after intubation.

\section{Personal opinions}

$80.9 \%$ of EPs are not willing to monitor intubated patients. Only $18.9 \%$ of the participants working in TRHs and UHs were willing to monitor intubated patients.

The negative comment most frequently stated by EPs (49.5\%) about MVM in ED was that "the theoretical and practical skills training given during EMTP was not standard or not adequate". The second most negative comment was "inadequacy of technical equipment" (41.2\%). The positive comment most frequently stated by the participants about MVM in ED was that "the clinic would gain prestige" (74.7\%). The most negative opinion was that; "the patients would stay longer in the ED" (91.5\%). The most emphasized solution suggested about MVM in emergency medicine was that "the physicians should be subject to rotations in clinics with high technical and educational conditions that will enable them to increase their application and practical skills" (Table 4). 
Table 3. Mechanical ventilation qualifications of participants per their institutions

\begin{tabular}{|c|c|c|c|c|c|}
\hline $\begin{array}{l}\text { Frequency of intubated } \\
\text { patient monitoring }\end{array}$ & $\begin{array}{l}\text { TRH } \\
\text { n (\%) }\end{array}$ & $\begin{array}{c}\text { UH } \\
\text { n (\%) }\end{array}$ & $\begin{array}{c}\text { SH } \\
\text { n (\%) }\end{array}$ & $\begin{array}{c}\text { PH } \\
\text { n (\%) }\end{array}$ & $\begin{array}{l}\text { Total } \\
\text { n (\%) }\end{array}$ \\
\hline I am not monitoring at all & $31(25.2)$ & $17(12)$ & $102(94.4)$ & $29(100)$ & $179(44.7)$ \\
\hline \multicolumn{6}{|l|}{ I am monitoring rarely } \\
\hline (a few times a month) & $44(35.8)$ & $32(23)$ & $6(5.6)$ & - & $82(20.5)$ \\
\hline \multicolumn{6}{|l|}{ I am monitoring intermittently } \\
\hline (not having more than one patients at a time) & $12(9.8)$ & $14(10)$ & - & - & $26(6.5)$ \\
\hline \multicolumn{6}{|l|}{ I am monitoring frequently } \\
\hline (having more than one patients at a time) & $24(19.5)$ & $40(29)$ & - & - & $64(16)$ \\
\hline \multicolumn{6}{|l|}{ I am always monitoring } \\
\hline (we are monitoring more than one patients at a time frequently) & $12(9.8)$ & $37(27)$ & - & - & $49(12.2)$ \\
\hline \multicolumn{6}{|l|}{ MV or SAV usage frequency } \\
\hline I am always using SAV & 19 (15.4) & $22(15.7)$ & $97(89.8)$ & $23(79.3)$ & $161(40.2)$ \\
\hline I am frequently using SAV & $44(35.8)$ & 27 (19.3) & $11(10.2)$ & - & $82(20.5)$ \\
\hline Using sometimes MV sometimes SAV & $7(5.7)$ & $11(7.9)$ & - & - & $18(4.5)$ \\
\hline I am frequently using MV & $36(29.3)$ & $47(33.6)$ & - & $6(20.7)$ & $89(22.2)$ \\
\hline I am always using MV & $17(13.8)$ & $33(23.6)$ & - & - & $50(12.5)$ \\
\hline \multicolumn{6}{|c|}{ Paralyzing agent usage frequency during intubated patient monitoring } \\
\hline Never & $5(4)$ & - & $88(81.4)$ & $28(96.5)$ & $121(30.2)$ \\
\hline Rarely & $7(5.6)$ & $7(5)$ & $9(8.3)$ & $1(3.4)$ & $23(6)$ \\
\hline Intermittently & $18(14.6)$ & $17(12.1)$ & $11(10.1)$ & - & $46(11.5)$ \\
\hline Frequently & $73(59.3)$ & $74(52.8)$ & - & - & $147(36.7)$ \\
\hline Always & $20(16.2)$ & $42(30)$ & - & - & $62(15.5)$ \\
\hline \multicolumn{6}{|c|}{ Sedative agent usage frequency during intubated patient monitoring } \\
\hline Never & $5(4)$ & - & $86(79.6)$ & $27(93)$ & $118(29.5)$ \\
\hline Rarely & - & - & $8(7.4)$ & $1(3)$ & $9(2.2)$ \\
\hline Intermittently & $14(11)$ & - & $6(5.5)$ & $1(3)$ & $21(5.2)$ \\
\hline Frequently & $72(58.5)$ & $58(41.4)$ & $6(5.5)$ & - & 34 \\
\hline Always & $32(26)$ & $82(58.6)$ & $2(1.9)$ & - & $116(29)$ \\
\hline
\end{tabular}

TRH: Training and research hospital, UH: University hospital, SH: State hospital, PH: Private hospital, MV: Mechanical ventilator, SAV: Single-use automatic ventilator. In the table institution column percentages are reflecting in-institution frequencies whereas percentages in the total column are reflecting the frequencies of research group.

\section{Discussion}

EMTP first began in Turkey in 1993 with the name "First and Emergency Aid, Specialization in Medicine Training Program". ${ }^{\text {"[] }}$ According to December 2011 data derived from the official web site of the T.R. Ministry of Health, it was determined that there are 567 EPs in Turkey.$^{[8]}$ In our survey study, we reached $70 \%$ of these EPs. Statistically, this is a high enough participation rate to reflect the overall situations of EPs in the country (in regional and institutional basis).

At the result of our study, we found that the factors effecting the MVM skill perception levels of EPs were "duration of professional experience in field of specialization", "existence of ICU in the ED", "training received during EMTP" and "clinic chief is from the field of emergency medicine". Factors that did not affect the MVM skill perception levels of EPs included "whether or not the technical and personnel infrastructural qualifications of ED are adequate" and "whether or not there is a simulation laboratory used for training".

In the study by Fiedler et al. on the role of experience in success, it was reported that individuals whose professional experience duration is longer often exert greater effort to be successful in their jobs, and as a result, they are more successful. ${ }^{[9]}$ In our study, it was found that as the experience 
Table 4. Personal assessment qualifications about mechanical ventilation management in ED

\begin{tabular}{|c|c|c|c|c|c|}
\hline \multirow{2}{*}{$\frac{\text { Participant opinions }}{\text { Deficiencies Stated }}$} & \multicolumn{5}{|c|}{ Institutions } \\
\hline & $\begin{array}{c}\text { TRH } \\
\text { n (\%) }\end{array}$ & $\begin{array}{c}\text { UH } \\
\text { n (\%) }\end{array}$ & $\begin{array}{c}\text { SH } \\
\text { n (\%) }\end{array}$ & $\begin{array}{c}\text { PH } \\
\text { n (\%) }\end{array}$ & $\begin{array}{l}\text { Total } \\
\text { n (\%) }\end{array}$ \\
\hline Unwillingness of physicians & $18(14.6)$ & $47(33.5)$ & $5(4.6)$ & $4(13.7)$ & $74(18.5)$ \\
\hline Training's not being standard or being inefficient & $61(49.5)$ & 99 (70.7) & $29(26.8)$ & $9(31)$ & $198(49.5)$ \\
\hline Physicians' considering necessary or suitable & $42(34.1)$ & $63(45)$ & $37(34.2)$ & $11(37.9)$ & $153(38.2)$ \\
\hline Unsuitability of patient profile & $42(34.1)$ & $14(10)$ & $33(30.5)$ & - & $89(22.5)$ \\
\hline Inadequacy of technical equipment & $50(40.6)$ & $58(41.4)$ & $51(47.2)$ & $6(20.6)$ & $165(41.2)$ \\
\hline \multicolumn{6}{|l|}{ Positive Opinions } \\
\hline Clinic gains prestige, have a say in the field & $94(76.4)$ & $100(71.4)$ & $84(77.7)$ & $19(4.7)$ & $297(74.7)$ \\
\hline Patient care will not be adversely affected & $52(42.2)$ & $67(47.8)$ & $31(28.7)$ & $8(27.5)$ & $158(39.5)$ \\
\hline Patient care will be better & $18(14.6)$ & $21(15)$ & $6(5.5)$ & $4(13.7)$ & 49 (14.2) \\
\hline ED income will be affected positively & $18(14.6)$ & $19(3.5)$ & $3(2.7)$ & - & $40(10)$ \\
\hline Satisfaction of patients and relatives will increase & $10(8.1)$ & $21(15)$ & $2(2.5)$ & - & $33(8.2)$ \\
\hline Number of personnel will increase & $9(7.3)$ & $14(10)$ & - & - & $23(5.7)$ \\
\hline \multicolumn{6}{|l|}{ Negative Opinions } \\
\hline Patient hospitalization duration will be longer & $113(91.8)$ & $126(90)$ & 99 (91.6) & $28(96.5)$ & $366(91.5)$ \\
\hline Patient care quality will be adversely affected & $31(25.2)$ & $39(27.8)$ & $16(14.8)$ & $6(20.6)$ & $92(23)$ \\
\hline Clinic mortality will increase & $13(10.5)$ & $34(24.2)$ & $11(10.1)$ & - & $58(14.5)$ \\
\hline Hospital infection risk will increase & $21(17)$ & $30(21.4)$ & $16(14.8)$ & $6(20.6)$ & $53(13.2)$ \\
\hline ED income will be adversely affected & $3(2.4)$ & $23(16.4)$ & $1(0.9)$ & - & $27(6.7)$ \\
\hline \multicolumn{6}{|l|}{ Solution Suggestions } \\
\hline Conducting morale and courage increasing activities & $29(23.5)$ & $18(12.8)$ & $6(5.5)$ & $2(6.8)$ & $55(13.7)$ \\
\hline Increasing number and quality of PGTP & $60(48.7)$ & $76(54.2)$ & $20(18.5)$ & $7(24.1)$ & $163(40.7)$ \\
\hline Making long term programs for the future of emergency medicine training & $49(39.8)$ & $85(60.7)$ & $20(18.5)$ & $7(24.1)$ & $161(40.2)$ \\
\hline Programming rotations that increase application and practical skills & $68(55.2)$ & $57(40.7)$ & $62(57.4)$ & $13(44.8)$ & $200(50)$ \\
\hline
\end{tabular}

PGTP: Post graduate training program; MV: Mechanical ventilator; ED: Emergency department; TRH: Training and research hospital; UH: University hospital; SH: State hospital; PH: Private hospital. In the table institution column percentages are reflecting in-institution frequencies whereas percentages in the total column are reflecting the frequencies of research group. Total has exceeded $100 \%$ since participants could choose more than one option.

duration of the EPs increased, their adequacy perception levels regarding MVM also increased. This result indicates that EMTP may be much more successful in the coming years.

The participants who worked in places that had an ICU in the ED had higher mean MVM skill perception levels than those who did not. This indicates that practice may lead to higher mean MVM skill perception levels.

In the study of Weinstein et al. on learning strategies, it was reported that individuals who receive training for a job before beginning that job exert greater effort towards being successful in their jobs, and as a result, they are more successful. ${ }^{[10]}$ In our study, we determined that participants who had training during and/or after EMTP felt more adequate and interested in MVM compared to those who had no training in either of these two periods.
Participating physicians working in clinics who had clinic chiefs from the field of emergency medicine perceived themselves as more adequate and interested as compared to those who did not. This result indicates that a clinic chief from the field of emergency medicine and a standard training program on MVM should be implemented at emergency medicine training clinics.

In spite of the many positive opinions reported in our study, $75 \%$ of the participants stated that they did not receive any hands-on training in MVM during or after EMTP. This result indicates that not enough time is set aside for MVM application in the curriculum of EMTP institutions.

In the study of Stock et al. on critical success factors and the reduction of hospital errors, it was reported that individuals working in hospitals whose personnel and technical equip- 
ment infrastructure are better exert a greater effort to be successful in their jobs. ${ }^{[10,11]}$

Also, in our study, we found that MVM effort perception levels were higher for participants whose personnel and technical equipment infrastructure adequacy level perceptions were adequate or very adequate. However, no relationship could be found between personnel and technical equipment infrastructure adequacy levels and MVM skill perception levels. This result suggests that the MVM skill perception levels of the participants are more a results of their training and not of the infrastructure and personnel resources in their place of work.

In our study, we determined that the mean skill perception levels of EPs in both invasive and non-invasive MV matters were "neither adequate nor inadequate". MV skill perception is one of the most important parts of critical patient care in $E D$, and inadequacies in this perception can cause low selfconfidence in physicians, which can lead to medical care deficiencies or errors.

No relationship was found between mean skill perception levels and the existence of simulation laboratories in the clinics. This result suggests that clinics with simulation laboratories either have inadequate equipment (in terms of MVM application) or that these laboratories are not used effectively.

The studies by Tobin et al. (2006, in England) and by Esteban et al. (conducted in 20 countries) reported that indications for MV application were respiratory distress and trauma. ${ }^{[12,13]}$ The results of our study were similar.

An important result from our study is that a large majority (89.8\%) of EPs working in $\mathrm{SH}$ s are using single-use automatic ventilators instead of mechanical ventilators for monitoring intubated patients. Less frequent monitoring of intubated patients in SH EDs might be due to technical and equipment deficiencies, since there are too few patients in these institutions to warrant the purchase of the necessary equipment.

In a multinational study carried out by the International Mechanical Ventilation Study Group, it was reported that only $68 \%$ of patients receiving MV support for more than 12 hours have received sedation during their MV support. ${ }^{[14]}$ In two studies (one of which was a multinational survey conducted by Soliman et al. with 647 intensive care physicians and the other conducted by O'Connor et al. on sedation usage during $\mathrm{MV}$ ) it was reported that the most frequently used sedative agents were midalozam and propofol, respectively. ${ }^{[15,16]}$ In our study, the sedative most frequently used in intubated patients was midazolam, followed by diazepam in frequency of use. We also found that if two medicines were used together as sedative agents, the most frequent combination was midazolam and propofol.

In both the study of $\mathrm{O}^{\prime}$ Connor et al. ${ }^{[16]}$ and the multinational study of Arroglia et al. ${ }^{[14]}$ it was reported that the most frequently used analgesic agents during MVM were morphine sulfate and alfentanyl. Similarly, in our study we found out that fentanyl was the most frequently used, while morphine sulfate was the second most frequently used analgesic agent. $16 \%$ of the EPs that participated in the study did not use analgesic agents, and $29.5 \%$ of those also did not use sedative agents during intubation.

In the national study of John et al. it was reported that vecuronium was the most commonly used neuromuscular blocking agent in MV patients. ${ }^{[17]}$ In our study, we observed that $30.2 \%$ of EPs did not use any paralyzing drugs, but of those who did, vecuronium was the most frequently preferred paralyzing agent.

It has been shown that sedative, paralyzing and analgesic agents provide sedation and comfort for patients in mechanical ventilation, enhance patient-ventilator harmony, increase gas exchange, and reduce barotrauma risk..$^{[18,19]}$ When compared to the current literature, we observed that the EPs in Turkey are using sedative and paralyzing drugs less frequently. This result suggests that there may be a deficiency in the knowledge and experience in MVM in Turkey. Therefore, an effort should be made to determine the reasons for the low use of sedative/paralyzing agents in MVM in EDs in Turkey, and solutions should be determined on how to increase their use.

When the increasing frequency of intubated patients in EDs in the recent years is taken into consideration, is obvious that it is necessary to update the curriculum in the subject of MVM, and to increase the number of training hours and hands-on laboratory training. In institutions where EMTP is offered, the existing simulation laboratories must be better equipped and more functional, and simulation laboratories that can be used effectively must be opened in clinics where EMTP is not offered.

Also, emergency medicine specialization societies must support hands-on courses and post graduate training programs in MVM. In the long term, national emergency medicine policies must be established by organizing common panels and conferences together with societies of anesthesiology and reanimation.

\section{Limitations}

Our study has the general limitation of survey studies. While interpreting our results, it must be kept in mind that our data includes the thoughts of EPs, which are subjective. 


\section{Conclusion}

EP skill reception levels of MVM are low. Training for MVM is thought to be inadequate. EPs are using sedative and paralyzing agents in MVM less often than is reported in the literature. Having an ICU in the ED or having a clinic chief from the field of emergency medicine increases the success perception of EPs who have received EMTP in MVM. Also, mechanical ventilation management education in emergency medicine education programs as well as infrastructural conditions of emergency departments with respect to mechanical ventilation were both considered as inadequate by emergency physicians.

\section{Conflict of Interest}

The authors declare that there is no potential conflicts of interest.

\section{References}

1. Sigillito RJ, DeBlieux PM. Evaluation and initial management of the patient in respiratory distress. Emerg Med Clin North Am 2003;21:239-58. [CrossRef]

2. Archambault PM, St-Onge M. Invasive and noninvasive ventilation in the emergency department. Emerg Med Clin North Am 2012;30:421-49. [CrossRef]

3. Orebaugh SL. Initiation of mechanical ventilation in the emergency department. Am J Emerg Med 1996;14:59-69.

4. Charles V, Pollack Jr. Mechanical ventilation and noninvasive ventilatory support. In: Marx JA, Hockberger RS, Walls RM, editors. Rosen's emergency medicine: concepts and clinical practice. 6th ed. Mosby, Inc. 2006.

5. Akbay A. Visual analog skala (VAS) değerlendirmesi. Türk Nöroşirurji Derneği-Spinal ve Periferik Sinir Cerrahisi Grubu. http://www.spinetr.org/skor/VizuelAnalogSkala.pdf?phpMy Admin $=58238 \mathrm{cb} 5 \mathrm{a} 2 \mathrm{deb} 6 \mathrm{fcf} 3 \mathrm{e} 67 \mathrm{cf} 148 \mathrm{c} 3 \mathrm{ded} 4$. Erişim tarihi: 06.05.2012.

6. Wewers ME, Lowe NK. A critical review of visual analogue scales in the measurement of clinical phenomena. Res Nurs Health 1990;13:227-36. [CrossRef]
7. Acil Tıp Yeterlilik Kurulu Yönergesi, Antalya 14 Kasım 2007. Türkiye Acil Tıp Derneği web sitesi. http://www.tatd.org.tr/ bilgi/acil_tip_yeterlilik_kurulu. Erişim tarihi: 06.12.2011.

8. T.C. Sağlık Bakanlığı web sitesi. http://personel.saglik.gov. tr/devlet-hizmet-yukumlulugu-id56-55.html. Erişim tarihi: 06.12.2011.

9. Fiedler EF, McGuire M, Richardson M. The role of intelligence and experience in successful group performance. Journal of Applied Sport Psychology 1989;1:132-49. [CrossRef]

10. Weinstein C, Mayer R. The teaching of learning strategies. In: Wittrock MC, editor. Handbook of research on teaching. 3rd ed., New York: Macmillan; 1986.

11. McFadden KL, Stock GN, Gowen CR 3rd. Exploring strategies for reducing hospital errors. J Healthc Manag 2006;51:123-35.

12. Tobin MJ. Advances in mechanical ventilation. N Engl J Med 2001;344:1986-96. [CrossRef]

13. Esteban A, Anzueto A, Frutos F, Alía I, Brochard L, Stewart TE, et al. Characteristics and outcomes in adult patients receiving mechanical ventilation: a 28-day international study. JAMA 2002;287:345-55. [CrossRef]

14. Arroliga A, Frutos-Vivar F, Hall J, Esteban A, Apezteguía C, Soto $L$, et al. Use of sedatives and neuromuscular blockers in a cohort of patients receiving mechanical ventilation. Chest 2005;128:496-506. [CrossRef]

15. Soliman HM, Mélot C, Vincent JL. Sedative and analgesic practice in the intensive care unit: the results of a European survey. Br J Anaesth 2001;87:186-92. [CrossRef]

16. O'Connor M, Bucknall T, Manias E. Sedation management in Australian and New Zealand intensive care units: doctors' and nurses' practices and opinions. Am J Crit Care 2010;19:285-95.

17. Hansen-Flaschen JH, Brazinsky S, Basile C, Lanken PN. Use of sedating drugs and neuromuscular blocking agents in patients requiring mechanical ventilation for respiratory failure. A national survey. JAMA 1991;266:2870-5. [CrossRef]

18. Schweickert WD, Gehlbach BK, Pohlman AS, Hall JB, Kress JP. Daily interruption of sedative infusions and complications of critical illness in mechanically ventilated patients. Crit Care Med 2004;32:1272-6. [CrossRef]

19. Mallon WK, Keim SM, Shoenberger JM, Walls RM. Rocuronium vs. succinylcholine in the emergency department: a critical appraisal. J Emerg Med 2009;37:183-8. [CrossRef] 